\title{
CONTACTS AND CULTURES
}

$\mathrm{T}$ HE proposal to found in London a mosque and Islamic cultural centre (see p. 712) will be a cause of gratification not only to those whose more immediate needs will be served by such an institution, but also to all who will welcome the enlarged opportunities it will afford of contacts between East and West, and of the fuller understanding which, if it does not remove, will at least lower the barriers between peoples of different cultures, beliefs, and traditional outlook. The project has taken form largely owing to the personal interest and effort of His Excellency Hassan Nashaat Pasha, the Egyptian Ambassador in London, and from the beginning it has received the patronage of King Farouk. The extent of the support it will receive in the Moslem world may be gauged from the composition of the influential committee preparing the scheme. It includes representatives of the Moslems of Arabia, of Iraq and of India in addition to those of Egypt.

The good will towards the Moslem community displayed by the British Government in its response to the appeal carries on the tradition of tolerance amid a diversity of creeds and cultural traditions, which for long has been among the more notable characteristics of British imperial rule, and now has been passed on to the British Commonwealth of Nations. It comes at an appropriate moment. The minds of men, even amid the intense pre-occupations of a bitter struggle for existence, are already casting about for solutions of the grave problems of a post-War world. Then, if all goes well, the "New Order" of democracy (to adopt Mr. Roosevelt's phrase) will be confronted with the task of recasting the conditions of life of the whole world. Not again, if we are to profit from past mistakes, will the determination of racial, or national boundaries completely fill the foreground and middle distance of the picture. It is permissible to predict that where they appear, if appear they must, it will be in the true perspective of their subordination to the general interests of the whole and not solely of the component parts. World order will, in fact, have to be adapted to conditions, some of which will have suffered a profound change, while others will have to be remoulded drastically and to a new purpose to avoid the pitfalls of the past.

Already the President of the United States invites the Americas to a co-operation based upon a spiritual unity. In Africa, General Smuts foreshadows a Union of African States. Such a union should afford an ever-increasing opportunity for those ameliorations of the conditions of human life and progress on that continent on a scale, not indeed undreamed of, but hitherto beyond the resources of individual administrative units. In Europe the agreement between Poland and Czechoslovakia opens the way to a post-War nucleus of stability in Central Europe, such as might have been formed in Western Europe had not the proposed co-operation between France and Great Britain proved abortive. Even more suggestive, because of the implications of close personal and cultural contacts, are Mr. Bevin's plans for the forging of a new industrial link between East and West by bringing some hundreds of men from the workshops of India to receive a training in the workshops of Great Britain. Thenceforward not only will India be in a position to make great strides towards fuller development of her potentialities in contribution to the world's output, at the same time raising her own standard of life, but also closer contact between individuals of both peoples will have brought fuller understanding of the problems of each.

Except in so far as such proposals can be given immediate practical effect, it is too early to attempt to evaluate them. They will have to stand the test of discussion and experience; but if the past history of the British Empire affords any criterion, their prospect of securing stability and co-operation will depend upon the degree to which they are framed to allow free play to individual cultural and traditional differences. Just as the proposed mosque in London, with all the intellectual and cultural activities of Islamic tradition associated with it, will take its place in contributing to the life and functions of the capital city of the British Commonwealth, so racial and national traditions will not, or should not, vanish in post-War adjustment, but should be preserved, so that each may make its appropriate contribution in the advancement of the general good of mankind-a general good which is not "the greatest good of the greatest number" with concessions to minorities, racial or other, but a good which admits of liberty for the individual to attain full stature, intellectual, moral and social. 